\title{
One Size Does Not Fit All: Land Markets and Property Rights for the Construction of the Just City
}

CLARA IRAZÁBAL

\begin{abstract}
This essay reflects on alternative urban markets and property right systems in some Latin American countries. What becomes clear is that one size does not fit all: land markets and property rights are multifaceted and their conception and implementation should be context-sensitive. In recent experiments and proposals in Brazil, El Salvador and Venezuela, among other countries, they are being used as instruments for the expansion of rights to the city and the construction of the just city.
\end{abstract}

There is an unbalanced focus on legal and economic considerations in discussions of land markets and property rights to the detriment of social and cultural issues, particularly in countries of large and expanding social inequality and polarization. In response to the criticism directed towards Anne Haila's article about not contributing alternatives to the approach(es) that she criticizes, this essay reflects on the alternative urban markets and property right systems that are currently under consideration or construction in some Latin American countries. What becomes clear is that one size does not fit all: land markets and property rights are multifaceted and their conception and implementation should be contextsensitive (Beauregard, 2005). In recent experiments and proposals in Brazil, El Salvador and Venezuela, among other countries, they are being used as instruments for the expansion of rights to the city and the construction of the just city.

\section{The right to the just city}

There is pervasive use (and abuse) of land markets and property rights as instruments to further the expansion of capitalist accumulation that expands socio-economic and spatial inequalities and polarization (Fernandes, 2008; Marcuse, 2008). Many legal and planning practices facilitate that project (Irazábal and Punja, 2009). Urban elites frequently implement mechanisms that effectively prevent or control the spatial practices of 'others' that deviate from the ethos of a 'consumerist citizenship'. These trends are so unapologetically pursued in some cities, that some call this the era of the 'post-justice city' (Mitchell, 2001), in which citizenship rights are taken away from those who cannot partake in the neoliberal economy (Weber, 2002; Miraftab and Wills, 2005; Irazábal, 2008). 
In this context, Lefebvre's $(1968 ; 1996)$ notion of 'the right to the city' offers a vision of a new urban politics where use value prevails over exchange value, i.e., that 'urban space should be produced to meet the everyday needs of those who inhabit it' (Purcell, 2005: 200; Purcell 2002). In Harvey's words, the right to the city should not be 'merely a right of access to what the property speculators and state planners define, but an active right to make the city different, to shape it more in accord with our heart's desire, and to re-make ourselves thereby in a different image' (2003: 940). Similarly, the conception of the 'just city' (Fainstein, 2000; Marcuse et al., 2009) proposes a normative approach to urban planning that combines progressive planners' traditional focus on socio-spatial and politicoeconomic equity with concerns for diversity, participation and sustainability to improve urban life for all within the context of a global capitalist economy.

The intensification and pervasiveness of urban challenges in many regions of Latin America have raised awareness about the need to question full property rights as an instrument that can secure shelter for the poor (Angotti, 1996; Marcuse, 2008; Irazábal, 2009).

\section{(In)formal land markets and property rights in Latin America}

From eradication of informal settlements through demolition to attempts at upgrading settlements and formalizing land tenure, the approaches used to address settlements in Latin America have varied from city to city and decade to decade. Since the 1960s, many land-use programs have focused on the legalization of land tenure. Land tenure, it is argued, gives people security of stay, a source of capital, and allows them to qualify for formal loans using their house or land as collateral. Many people thus develop a greater sense of belonging and are more willing and able to invest resources and efforts in improving their communities. Thus, demolition and eviction practices of informal settlements, which used to be common in the past, are rarer nowadays. For more established communities that are not threatened with eviction or demolition and have thus achieved de facto tenure, however, land tenure is not necessarily very attractive. Residents of favelas in Rio de Janeiro, for instance, are often opposed to regularization of land titles. Contrary to a common shared belief among analysts (de Soto, 2000; Varley, 2002), professional planners and international organizations (e.g. the World Bank), many informal settlement residents do not want to be subjected to property taxes or building codes and are not attracted to formal credit systems because they do not have a steady income to repay debts (Perlman, 2005).

As a result, land acquisition and development in Latin America have become increasingly informalized. However, many informal settlements in Latin America, particularly those in central urban locations with great connectivity and accessibility, are subjected to competitive property and rental markets, even if informally. The supply of developable urban land has become steadily constricted, while demand has remained high in cities throughout the region, leading to steep increases in the costs of attaining and developing urban land. Furthermore, formal land regulation processes such as the development approval process often further restrict land supply, therein augmenting land and housing costs. Access to land is thus one of the most visible struggles in Latin America (Wigle, 2008) and one of the greatest determinants of livelihood and quality of life for city dwellers. These obstacles often push people to settle in more remote, peripheral urban areas, therein leading to further difficulties in terms of acquiring land tenure and servicing land.

After the wave of national democratization and municipal devolution of power that swept the region in the last decades of the twentieth century, many residents of cities in Latin America started demanding a voice in processes that impact the fate of their communities and places (Holzner, 2007; Klesner, 2007), and there have been significant political changes that have resulted in new planning legislation and initiatives (Irazábal, 
2009). These changes have also imbued local governments with new tools to control land management and challenge land-use patterns. This is a marked deviation from historic landuse policies in the region that privileged private over public rights and reduced the effectiveness of planning institutions.

\section{Innovative land-use planning approaches}

There are some notable examples of innovative and cost-effective land-use planning approaches that are beginning to reshape cities in Latin America while improving living conditions for the poor. Some recent examples encompass agrarian and land reforms and proposals in Brazil, El Salvador and Venezuela, in addition to Nicaragua, Colombia, Cuba, Ecuador, Bolivia and Paraguay (Wiesenfeld, 1997; Varley, 2007).

In Brazil, for example, two major political events have begun to take shape with a change in political power. In 2001, the City Statute expanded constitutional provisions to imbue municipalities with tools to control growth and challenge land-use patterns. This statute recognizes 'the power and obligation of municipal governments to control the process of urban development through the formulation of territorial and land-use policies, in which the individual interests of land owners necessarily co-exist with other social, cultural and environmental interests of other groups and the city as a whole' (Fernandes, 2007: 182). Brazil's Statute of the City and its use of ZEIS zoning (zones of special social interest) formalize and protect the occupied land of the urban poor. The City Statute has been further promoted with the formation of the Ministry of Cities in 2003. Its National Programme to Support Sustainable Urban Land Regularization has focused on methods to articulate and mobilize intervention strategies that combine legal, financial, planning and political elements to promote regularization of settlements and to provide residents with land tenure rights to varying degrees.

Grassroots movements such as the Movimento dos Trabalhadores Rurais Sem Terra (MST, the Landless Rural Workers) and Movimento Sem Teto do Centro (MSTC, the Roofless Workers of the Center) have also provided a way for the rural and urban poor to obtain land and accommodation. However, how to resolve outstanding title disputes with land-owners and to provide sufficient services and infrastructure for occupied properties remain to be tackled. Formed in 1984, the MST has promoted non-violent occupation of unproductive land, agrarian reform (defined not only by the redistribution of land but also policies that would develop and sustain rural families), and a more just society (Plummer and Ranum, 2002). Its urban counterpart, MSTC, reclaims buildings for poor urbanites working in lowincome jobs. As of 2007, as many as 400,000 urban families had been allotted land through MSTC (Phillips, 2006; Duffy, 2007).

Some countries have begun to reduce land development standards in an effort to streamline land development regulation and implementation. For example, El Salvador reformed land policies to encourage faster and cheaper development. It reduced requirements for subdivision layout, and required only provision of water and sanitation services to be in place for development to begin, permitting infrastructure to be updated incrementally. In doing so, land development has begun to increase apace and decrease in costs. Now, lowincome lot development accounts for one-third of all new housing development in E1 Salvador, and lot prices have decreased by $20 \%$ since 1996 (Ferguson and Navarrete, 2003). A challenge remains for the benefits of community improvement programs to remain in the community and not to get transferred to wealthier residents through a process of gentrification. Some programs of land banking, social interest zoning (ZEIS), condominium ownership, non-elitist urban regulations, a progressive fiscal mechanism for land value capture, and 'right of use' of land have addressed these challenges (Boyer, 2005; Acioly, 2007; Fernandes, 2008; Marcuse, 2008).

The land reforms in the region have their impasses too. In Venezuela, a project to change 33 of the 350 articles of the National Constitution was narrowly defeated in a referendum in December 2007. Based on consolidating and expanding communal power, 
the reform aimed to transform the bureaucracy and to provide the president with more ways to maneuver around the obstacles to decentralization, devolution and the socialization of the economy. The new classification of property would have left the right to and protection of private property unchanged, together with the right of the government to take property for 'public good' purposes and with adequate compensation (similar to provisions in the US and Western Europe). As suggested in the reform, however, non-private property could be classified as public (fully owned and managed by the government); social (owned by the people and either managed by the government or by communities or other institutions); collective (owned and managed by groups of individuals for their particular uses); and mixed (a combination of ownership and management). The new classification of property was meant to support further diversification of models of social organization and economic activity (Irazábal, 2007).

The integration of physical and social planning in the consideration of, and responsiveness to the land needs of millions of residents throughout the region that do not have access to market rate property is the key to the success of innovative planning proposals and approaches to land development in Latin America.

\section{Moving forward}

For the creation of just policy, planning and development interventions in Latin America and other 'developing' regions, and in line with the various constitutions and international treaties that declare housing to be a human right, property rights would have to be redefined and made more flexible to expand use rights - including rights to build, modify, expand, access urban services, recuperate investments in improvements if the house is expropriated, and post-mortem transfer of rights to relatives (Marcuse, 2008). Innovative legal and political reforms have to find a balance between individual security of tenure and social rights to housing, secure women's equitable rights, and promote market controls so that the benefits of public investment are captured by residents and not by real estate developers (Fernandes, 2008). Some Latin American cities and countries are making hopeful and daring attempts to secure the expansion of rights to the city for all, and particularly their most disenfranchised residents. To accelerate the pace of change, practitioners and scholars ought to share best practices on policies that have been effective in reducing slum formation and securing land/housing tenure in developing and transitioning economies (Acioly, 2007); but also in the most advanced neoliberal ones, which have seen their social polarization grow. Global expertise in urban planning and land management can be applied locally. However, it has to be creatively adjusted as necessary in order to be context-sensitive and to contribute to the creation of the just city throughout the world.

\section{References}

Acioly, C. (2007) The challenges of slum formation in the developing world. Land Lines 19.2 (April) 2-7, Lincoln Institute of Land Policy. (Available at https://www.lincolninst.edu/pubs/d1/1220_LLA070402\%20Challenge\%20of\%20Slum\%20Formati on.pdf)

Angotti, T. (1996) Latin American 'urbanization and planning: inequality and unsustainability in North and South. Latin American Perspectives 23,4, 12-23.

Beauregard, R. (2005) The textures of property markets: downtown housing and 
office conversion in New York City. Urban Studies 42.13, 2431-45.

Boyer, H. (2005) Urban land and housing challenges in Brazil. Land Lines 17.4 (October), Lincoln Institute of Land Policy [WWW document]. URL http://www.

lincolninst.edu/pubs/PubDetail.aspx? pubid=1059 (accessed 21 June 2008).

de Soto, H. (2000) The mystery of capital: why capitalism triumphs in the West and fails everywhere else. Basic Books, New York.

Duffy, G. (2007) Brazil's homeless and landless unite. BBC News [WWW document]. URL http://news.bbc.co.

uk/2/hi/americas/6563359.stm (accessed 1 July 2008).

Fainstein, S. (2000) New directions in planning theory. Urban Affairs Review 35.4, 451-78.

Ferguson, B. and J. Navarrete (2003) New approaches to progressive housing in Latin America: a key to habitat programs and policy. Habitat International 27.2, 309-23. Fernandes, E. (2007) Implementing the urban reform agenda in Brazil. Environment and Urbanization 19.1, 177-89.

Fernandes, E. (2008) Do código civil ao estatuto da cidade [From the civic law to the city statute]. In M. Valença, (ed.), Cidade (I)legal [(Il)legal city], Mauad X, Rio de Janeiro.

Harvey, D. (2003) The right to the city.

International Journal of Urban and Regional Research 27.4, 939-41. Holzner, C.A. (2007) The poverty of democracy: neoliberal reforms and political participation of the poor in Mexico. Latin American Politics and Society 49.2, 87-122.

Irazábal, C. (2007) Constitutional reforms in Venezuela foretell a planning revolution. Progressive Planning (Fall), 33, 37. Also available at: http://www.plannersnetwork. org/publications/magazine.html

Irazábal, C. (2008) Introduction: Citizenship, democracy and public space in Latin America. In C. Irazábal (ed.), Ordinary places, extraordinary events: citizenship, democracy and public space in Latin America, Routledge. London.

Irazábal, C. (2009 forthcoming) Revisiting urban planning: Latin America and the Caribbean. Regional Report for the United Nations Human Settlement Programme's seventh issue of the Global Report on Human Settlements, Revisiting Urban
Planning. (Available at http://www. unhabitat.org/content.asp?typeid=19\&catid $=555 \& \mathrm{cid}=5607$ )

Irazábal, C. and A. Punja (2009) Cultivating just planning and legal institutions: a critical assessment of the South Central Farm struggle in Los Angeles. Journal of Urban Affairs 31.1, $1-23$.

Klesner, J.L. (2007) Social capital and political participation in Latin America: evidence from Argentina, Chile, Mexico, and Peru. Latin American Research Review 42.2, 1-32.

Lefebvre, H. (1968) Le droit à la ville. Anthropos, Paris .

Lefebvre, H. (1996) Writings on cities. Translated by E. Kofman, Blackwell, Oxford.

Marcuse, P. (2008) O caso contra os direitos de propiedade [The case against property rights]. In M. Moraes Valença (ed.), Cidade (I)legal [(Il)legal city], Mauad X, Rio de Janeiro.

Marcuse, P., J. Connolly, J. Novy, I. Olivo, J. Potter and J. Steil (eds) (2009) Searching for the Just City: debates in urban theory and practice. Routledge, Taylor \& Francis Group, New York/London.

Miraftab, F. and S. Wills (2005) Insurgency and spaces of active citizenship: the story of Western Cape anti-eviction campaign in South Africa. Journal of Planning Education and Research 25.2, 200-17.

Mitchell, D. (2001) Postmodern geographical praxis? The postmodern impulse and the war against the homeless in the post-justice city. In C. Minca (ed.), Postmodern geography: theory and praxis, Blackwell, Oxford.

Perlman, J. (2005) The myth of marginality revisited: the case of a favela in Rio de Janeiro, 1969-2003. World Bank,

Washington. [WWW document]. URL http://www.worldbank.org/urban.urscd/ papers/perlman.pdf (accessed 21 June 2008).

Phillips, T. (2006) Brazil's roofless reclaim the cities. The Guardian [WWW document]. URL http://www.guardian. co.uk/world/2006/jan/23/brazil.uknews1 (accessed 1 July 2008).

Plummer, D. and B. Ranum (2002) Brazil's landless workers movement - Movimiento de Trabajadores Rurales Sem Terra - MST. Social Policy 33.1, 18-22. 
Purcell, M. (2002) Excavating Lefebvre: the approaches. World Development 35.10, right to the city and its urban politics of 1739-53. the inhabitant. Geojournal 58.23, Weber, R. (2002)

Extracting value from the 99-108. city: neoliberalism and urban

Purcell, M. (2005) Review of The right to the redevelopment. Antipode 34.3, 519-40. City: social justice and the fight for public Wiesenfeld, E. (1997) From individual need space by D. Mitchell. Antipode 37.1, to community consciousness: the dialectics 199-202. between land appropriation and eviction

Varley, A. (2002) Private to public: debating threat. Environment and Behavior 29.2, the meaning of tenure legalization. 198-212. International Journal of Urban and Wigle, J. (2008) Shelter, location, and Regional Research 26,449-61. livelihoods: exploring the linkages in

Varley, A. (2007) Gender and property Mexico City. International Planning formalization: conventional and alternative Studies 13.3, 197-222. 